\title{
Musical Performance and the Changing City: Post- Industrial Contexts in Europe and the United States
}

\author{
Fabian Holt \& Carsten Wergin (eds.) \\ New York \& London: Routledge \\ ISBN: 978-0-415-64486-0
}

\author{
lan Rogers \\ RMIT Univeristy, Melbourne \\ ian.rogers@rmit.edu.au
}

This new collection from Routledge, edited by Fabian Holt and Carsten Wergin, presents a timely and broad-reaching survey of music performance's role in the urban setting. Spread across eleven chapters and three sections (Placemaking, Scenes and Venues, Nightlife), Musical Performance and the Changing City presents a rich and descriptive set of case-studies, for the most part drawing on various primary sources and often aiming to situate the reader within the city or the venue or the community as much as within the theoretical coordinates of urban music research. Throughout, the theme of music's far-from-benign power is a prominent and highlighted point. This is live music performance conceived of as a cultural tool, with many different stakeholders reaching for the handle.

This focus on live music as an 'instrument of power' evolving within 'the urban order' (1) manifests itself through chapters on music's part in city branding projects, urban gentrification, the energizing and co-creating of music spaces (venues, clubs, public spaces) and in the daily individual and communal lives of people responding to these changes and upheavals. Sara Cohen's opening chapter 'From Big Dig to the Big Gig' on Liverpool presents live performance as a frame through which flows broader and deeper debates surrounding urban renewal and the exercise of governmental power. Meanwhile, Fabian Holt's piece, 'The Advent of Rock Clubs for the Gentry', investigates venues and clubs in three cities (Berlin, Copenhagen and New York), positioning these oft-beloved places as harbingers of gentrification and neighbourhood change. O'Meara and Tretter's look at Austin, Texas in 'Sounding Austin' proved interesting, focusing as it does on the marketing of live performance itself, as opposed to one of live music's more specific or general manifestations:

Austin's marketing has not become welded to any particularly profitable or exportable genre, style or scene, despite the success of progressive country in the 1970s. Instead, Austin has banked its financial fortunes on the more inclusive, more protean, and more amorphous category of live music as its city brand (57).

This, of course, proved problematic in the doing, with various notable exclusions made to Austin's music scene when it came time to organise and promote said 'amorphous category'. Similarly, I also found Inigo Sanchez Fuarros' chapter on Cuban musicmaking in Barcelona particularly fascinating as it tracked the tensions found in migrant 
community music as it served to both bolster the city's cosmopolitan branding while providing a forum for (often empowering) responses from the community itself. Throughout the collection, the field data appears rich and, for the most part, well deployed; my only quibble was with David Grazian's introduction of the 'microscene' which felt a little overstated but nonetheless appeared in amongst persuasive research material on Philadelphia DIY music practice.

Potential readers would be wise to note that this volume originates from an interdisciplinary workshop (Humanities Spring from the European Science Foundation, 2007) and a panel from the annual European Association of Social Anthropologists conference in 2008. As such, the collection does feel a little granular in its individual chapter foci. The depth of the fieldwork on display balances much of this. On the page, there is a real sense of place and experience exhibited. What these researchers appear attuned to and situated within are the places they describe and the power of the collection stems largely from this detail. For students or researchers of the individual cities or scenes described, this will be an invaluable resource albeit one seldom read cover-to-cover. For those squarely interested in urban studies and popular music, this may prove more interesting, indeed essential.

As a whole, the findings here appear clear: music is still a foundational communicative process by which we can take the temperature of a place or city. As a means to investigate the affective dimension of people moving through, or residing in, an urban space, live music's potential feels almost boundless. The various music formations described here are as varied as the people socially enacting them; they are not always entirely positive and just executions of power, nor are they ever entirely consumed by governance or strategic representation. Instead, what comes out of Musical Performance and the Changing City is a sense that music remains as pliable as ever. This volume gives voice to the affective power and flexibility of live music and as such reveals its continued relevance in our urban lives. 